\title{
Producing Peanuts Using Conservation Tillage ${ }^{1}$
}

\author{
D. L. Wright, B. L. Tillman, P. Devkota, and I. M. Small²
}

Peanuts are a very important part of the row crop economy in Florida, which is the third and sometimes the second largest of the 10 peanut-producing states in the United States. While peanuts are a high-management, high-input crop and the costs of inputs have steadily increased, peanut farmers are competing in a global market, and prices have remained low. Yields have increased to nearly 4,000 lb/A from 3,200 lb/acre mainly because of new varieties, although there have been advances in technology. To remain competitive, farmers must find ways to improve production efficiency or increase yields. Therefore, major trends in US agriculture over the past 10 years have included a move to genetically modified crops, reduced tillage, and precision application of inputs. Peanut production has traditionally been a tillage-intensive operation, but conservation tillage (or strip-tillage, as it is known by producers in the Southeast) has become a widely accepted practice for most row crops and is gaining acceptance among peanut farmers.

The mid- to late 1970s saw the first commercial production of strip-till soybeans and corn in Florida. No-till without subsoiling had not been successful due to the natural compacted soil layer of Coastal Plain soils preventing deep root growth, limiting rooting to the top 6-8 inches of soil. This restricted root system resulted in low yields when rainfall was inadequate, or irrigation was unavailable or limited. There was also limited planting equipment available to make strip-tillage work, less equipment for weed control, and fewer weed control options. Many of the equipment limitations and weed control options have been worked out over the last 25 years. Most conservation tillage planting units now include in-row subsoil shanks that break the soil compaction layer while leaving the row middle undisturbed. Beginning in 1995, transgenic or Roundup Ready soybeans and cotton came on the market, which allowed Roundup to be applied over the crop for weed control. In recent years, much of the corn crop is glyphosate-tolerant. This led to widespread adoption of strip-till planting of these crops, since weed control was no longer the major concern of strip-till farmers. Many of the new cotton growers or those expanding their acreage are farming all of their cotton using strip-tillage. However, peanut farmers have been slow to move to conservation tillage, partially due to the belief that plant residue left on the soil surface causes increased disease problems on peanut or makes digging harder. Growers had little incentive to change a program that had not only worked successfully for many years but often supported other parts of the farming operation. However, many studies over the past 25 years have shown that disease pressure is the same or less when planting into a cover crop, compared to the plow/ plant method of peanut production. This has also been the case with tomato spotted wilt virus (TSWV), which is one of the most limiting diseases to peanut production in the

1. This document is SS-AGR-185, one of a series of the Agronomy Department, UF/IFAS Extension. Original publication date September 2002. Revised April 2020. Visit the EDIS website at https://edis.ifas.ufl.edu for the currently supported version of this publication.

2. D. L. Wright, professor, Agronomy Department, UF/IFAS North Florida Research and Education Center; B. L. Tillman, professor, Agronomy Department, UF/IFAS NFREC; P. Devkota, assistant professor, Agronomy Department, UF/IFAS West Florida REC; and I. M. Small, assistant professor, Plant Pathology Department, UF/IFAS NFREC; UF/IFAS Extension, Gainesville, FL 32611.

The use of trade names in this publication is solely for the purpose of providing specific information. UF/IFAS does not guarantee or warranty the products named, and references to them in this publication do not signify our approval to the exclusion of other products of suitable composition.

The Institute of Food and Agricultural Sciences (IFAS) is an Equal Opportunity Institution authorized to provide research, educational information and other services

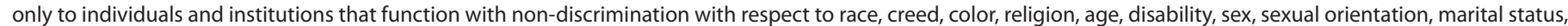

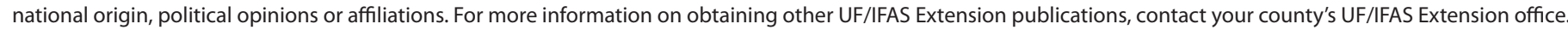
U.S. Department of Agriculture, UF/IFAS Extension Service, University of Florida, IFAS, Florida A \& M University Cooperative Extension Program, and Boards of County Commissioners Cooperating. Nick T. Place, dean for UF/IFAS Extension. 
Southeast. Other factors such as fuel costs have led many growers to switch to conservation tillage. This situation, along with years of success planting corn, cotton, and soybean using conservation tillage techniques, has led to widespread use of strip-tillage in peanut production. However, weed resistance has resulted in farmers needing to learn how to use herbicides with residual activity again for weed control. Fortunately, there are many good options for cotton, peanut, and other row crops.

\section{Getting Started}

Implementing new farming practices creates new challenges and risks. Proper preparation of fields a year in advance, land selection, crop rotation, type of cover crop, pest management, soil fertility, and type of equipment are all necessary to ensure a successful crop. UF/IFAS Extension agents and Natural Resources Conservation Service personnel can help provide a management plan for successful conversion to strip-till production of peanut and can also provide references to Extension specialists and farmers already involved in strip-till production, along with potential incentive funding for equipment purchases.

Weather is the biggest uncontrolled factor that puts the crop at risk. Irrigation, preplanning, and discussions with experienced farmers can take some of the uncertainty out of the equation, but poor weather at harvest can still cause major crop losses. Although it cannot overcome all of the stresses that weather might bring, strip-tillage can help reduce erosion and conserve moisture. Advantages associated with strip-tilling peanuts, besides moisture preservation, include less sandblasting and erosion, a reduction in labor, fuel, and equipment repairs, more time for management, and less TSWV and other diseases. The total benefit to using strip-tillage for a 1,000-acre farm in Florida has been calculated to be $\$ 16,000$ if yields are the same for both systems (http://agecon.uga.edu). Some of our strip-tillage/conventional tillage research with cotton has shown as much as a $\$ 75 / \mathrm{A}$ advantage to strip-tillage with yield increases where over-the-top herbicides can be used. Many farmers who have been in strip-till crop production for several years have said they would quit farming before going back to plowing and using conventional tillage practices.

There are many steps to follow to ensure successful production of strip-till peanuts. These are no different from any other crop using strip-till planting. Any method of growing peanuts should include a well-planned approach to production and marketing. Planning for strip-tillage normally starts the year before all of the equipment is in place with selection of fertilizers, fields, and cover crops.

\section{Fertilization}

Direct fertilization is not as critical for peanuts and soybeans as it is for some crops, and strip-till and conventional-till peanuts have the same fertilization requirements. However, special attention should be paid to calcium $(\mathrm{Ca})$, boron $(\mathrm{B})$, and $\mathrm{pH}$ in either tillage system. For more information on the fertilization of peanuts, see EDIS document SS-AGR-74, Management and Cultural Practices for Peanuts (https://edis.ifas.ufl.edu/aa258). Research in Georgia (Gascho 1996) has shown that lime should not be turned under before planting peanuts. Although $\mathrm{pH}$ adjustment will occur, it will have little to no effect on Ca uptake by pods. With strip-tillage, lime should be applied well in advance of planting if the subsoil is very acidic, or it should be incorporated prior to planting cover crops in the fall. Peanuts grow best at a $\mathrm{pH}$ around 6.2. Availability of soil nutrients and nitrogen fixation are optimized in this range. Zinc toxicities can occur when the $\mathrm{pH}$ is below 5.5. Manganese deficiency may occur when the $\mathrm{pH}$ is above 6.2. The liming program should be based on a soil test and dolomitic or calcitic limestone should be used to obtain the target $\mathrm{pH}$ range. Peanuts have a high Ca requirement; samples for soil tests should be from both the top 2-3 inches and 6 inches to ensure that adequate $\mathrm{Ca}$ is available in the pegging zone of strip-till peanuts. There should be at least $250 \mathrm{ppm}$ of $\mathrm{Ca}$ and a 3:1 Ca:K ratio or higher for runner peanuts. All Virginia-type or large-seeded peanuts, or those grown for seed, should receive additional $\mathrm{Ca}$ regardless of soil test levels. Apply 200-500 lb/A of dry gypsum over the row at early bloom to meet this additional Ca need. It is much more critical to apply gypsum on nonirrigated peanut than irrigated peanut because Ca moves to the pegs of peanut in soil water. Gypsum contains about $20 \% \mathrm{Ca}$ and about $16 \%$ sulfur. Boron is critical to flowering, pod development, and nut quality. Usually a half pound of $B$ is adequate to meet the needs of a peanut crop. This may be applied with preplant fertilizer or with an early fungicide application. Boron should be applied prior to early bloom.

Peanuts are very good at using residual nutrients from the previous crop or cover crop. Seldom do peanuts respond to direct fertilization of phosphorus or potassium. Therefore, if peanuts are in rotation with adequately fertilized crops, no phosphorus or potassium will be needed. Production of peanut on deep sand is an exception and requires some potassium at planting. Potassium may be needed as a top-dress application as well. 


\section{Variety Selection}

New runner-type peanut varieties with some resistance to TSWV, leaf spot, and Cylindrocladium black rot (CBR) are being introduced. These varieties also have other unique oil and maturity characteristics. In variety trials across the Southeast, no differences have been noted in variety response to tillage. Therefore, varieties should be chosen based on yield, grade, and pest resistance, and then on the basis of maturity that best fits the farming operation. Varieties range in maturity from about 125 days to almost 160 days. Pay careful attention to those varieties that perform best in multiple years over a wide range of management conditions.

\section{Rotations and Cover Crops}

Good rotations increase crop yields, reduce pests, and recycle nutrients. Grass crops benefit from nitrogen produced by previous legume crops, and peanuts usually do best after grass crops-especially after bahiagrass. Growers have always tilled up bahiagrass when planting peanuts in those fields. However, recent unpublished research has shown that peanuts can be strip-tilled into bahiagrass if it is killed in the fall and cover crops are planted over the winter (Table 1). If bahiagrass is killed in the spring, it should have some tillage to attain highest yields. Likewise, running the strip-till rig twice over the same row prior to planting results in a good seedbed and highest yields. Rows can often be laid off 2-3 weeks before planting and the strip-till rig with planters can be run again at planting time.

Rotations also help growers plan labor needs for planting and harvesting. Crops have different planting and maturity dates as well as different water requirements. Rotations decrease the risk of a total crop loss if severe drought occurs at a critical growth period for one crop but not for another. Much is known about rotating peanuts with grass crops. Crops like perennial grasses, corn, grain sorghum, millet, cotton, and small grains have been shown to benefit peanuts when planted as the preceding crop. Some of the benefits are use of residual fertility, less disease, and better weed control due to different modes of action of herbicides used on preceding crops. If peanuts follow peanuts, leaf spot starts earlier and takes more fungicide for disease control than when peanuts follow one of the grass crops. Peanut root-knot nematode and soilborne diseases such as stem rot (white mold) can become serious problems if peanuts follow peanuts. Initially, yields may not always be a great deal lower, but the expense of growing the crop will be higher due to the need for extra pest management. Figure 1 shows peanut plants grown in the greenhouse with the same soil type but with bahiagrass roots mixed in the soil with the plant on the right.

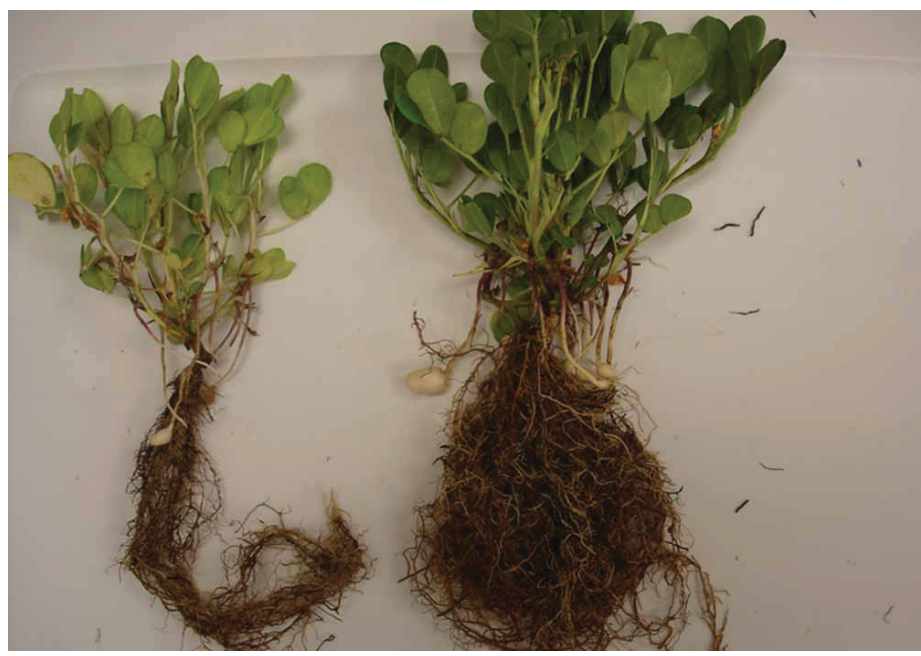

Figure 1. Greenhouse-grown peanuts with bahiagrass roots mixed in the pot of soil (right) vs. no bahiagrass roots (left). Nodulation, root growth, and top growth were greater from plants with bahiagrass roots in the soil.

Credits: UF/IFAS

Many growers begin to strip-till by planting into the previous crop's residue. They may do this because they are not accustomed to planting cover crops and/or do not know the value a good cover crop can contribute to the primary crop. However, plant residue can create problems if it is not managed properly or if equipment has not been properly set to cut through the residue. Strip-tillage can be successful without a cover crop, but this option will not reap many of the benefits of a good mulch residue. Some of the benefits of a good cover crop versus previous crop residue include:

- less soil erosion;

- increased moisture retention during periods of high rainfall;

- increased organic matter when managed for high residue production;

- reduction in sand blasting on the emerging crop;

- higher levels of water infiltration;

- higher microbial populations; and

- possible use for winter grazing, which further enhances microbial activity.

A good cover crop should be planned in much the same manner as the main crop. Small grain cover crops or perennial grasses are better than legume cover crops at building organic matter. Legume cover crops have very little fiber in the plant tissue and decompose rapidly. They will release most of the $\mathrm{N}$ from the plant tissue in the first 30 days after being killed. Most legume cover crops mature later in the 
spring than small grains and therefore must be killed before much dry matter is produced. In addition, most legumes are susceptible to root-knot nematode and may have diseases similar to those in peanut or soybean. Therefore, legumes are not recommended to plant prior to peanut production. Small grains (wheat, oats, rye) can be planted over a wide period on more infertile soils than many of the legumes. Small grain should be killed 4-5 weeks ahead of planting to prevent soil moisture depletion, to reduce cutworm, southern corn rootworm, and other soil pests, and to minimize potential phytotoxic effects from the cover crop. Small grain cover crops planted in November can be top-dressed with about $30 \mathrm{lb}$ N/A and 2,4-D in late January or early February. The application of 2,4-D will kill many of the winter broadleaf weeds and make the small grain cover crop and weeds easier to kill in late March when the small grain is headed out. Nitrogen will stimulate growth of the small grain for better cover. In cases where the cover crops are grazed, soil microbial populations as well as nutrients available to the following peanut crop increase. With 10 years of grazed vs. non-grazed cover crops, yields of peanuts have not been different. However, enhanced rooting (almost twice the size) has been noted after grazing, which leads to less stress and less aflatoxin as well as lower irrigation requirements. This enhanced root system may be valuable for non-irrigated crops or on soils that are less fertile. Generally, other crops show a yield enhancement after grazing cover crops. Peanut seed germination may be slower with early planting in conservation tillage with heavy cover crops than in conventional tillage due to lower soil temperatures. Our data have shown that soil temperatures can be 25 degrees cooler on the soil surface with straw mulch compared to bare soil between peanut rows on plowed fields during the summer months. Canopy temperatures have been measured to be 5 degrees cooler in strip-till compared to conventionally tilled peanuts $\left(96^{\circ} \mathrm{F}\right.$ vs. $101^{\circ} \mathrm{F}$ ). Likewise, available soil moisture was $30 \%$ higher during periods of hot, dry weather where the mulch was present. Bahiagrass or bermudagrass provides the best rotation crop for peanut because each results in a significant yield increase due to reduction of plant-parasitic nematode populations, increased organic matter and soil tilth, and grass roots that penetrate the compaction layer, leaving channels for the peanut roots to follow into the subsoil. Systems research now shows that bahiagrass can economically be used in crop rotations, with profits twice as large as those of a continuous row crop system.

\section{Planting and Management}

Farmers who are considering strip-tilling for the first time should talk to growers who have had experience with strip-tillage so they can plan prior to the season-preferably the year before, when management of the cover crop can be considered. Since tillage operations are eliminated, the planting operation should be timely. However, farmers should be aware that certain cover crops are hard to kill at certain growth stages, depending on the herbicides used, or that rollers may not fully kill the cover crop, resulting in competition to the following crop. Some of the winter weeds can be very difficult to control in the growing crop if not controlled before planting. Glyphosate alone will not control several broadleaf weeds. Therefore, other herbicides need to be used in combination or in sequence along with residual herbicides to control glyphosate-resistant weeds. After successfully killing the cover crop, 3-5 weeks are required for the weeds or cover crop to become brittle so planting can be done with ease. However, producers with livestock may allow grazing of the field up until a few days before planting, which will require a soil insecticide to control root-feeding insects that were present on the living forages.

Proper adjustment of strip-till equipment is essential to adequately prepare a seedbed and plant in the same pass if just one pass is made to strip and plant. Blowout is one of the main problems encountered by those new to striptillage, in which big patches of the cover crop are pulled up and a rough seedbed is left for the planter. The main cause of blowout is the cutting coulter in front of the subsoil foot not cutting deep enough. The subsoil foot pulls the plants out by the root, leaving an uneven planting surface. Lowering the depth of the front-cutting coulters so the coulters of the strip-till rig can cut deeper into the cover crop usually solves this issue. Generally, if the toolbar of the strip-till rig is level, this will not be a problem. Another cause of blowout is that the cover crop has not been killed far enough ahead of planting. These stems are still tough, and the coulters cannot cut through the residue, causing dragging and poor seedbeds. This can be solved by relocating to another field that was killed earlier or making sure that you have 3-5 weeks between killing the cover crop and planting. Although it is normally easier to plant through completely green cover crops or those that have been killed within 4-5 weeks, green cover crops can harbor insects and dry out the soil for the crop being planted. After a few years, the coulter on the strip-till rig will wear until it becomes too small to adequately cut through the cover crop, and poor seedbeds may result in spite of adjustments. If this occurs, replace the 
cutting coulter with the largest one that can be mounted on the strip-till rig.

Data from Florida, Georgia, and Alabama (Balkcom et al. 2010) with certain peanut varieties have shown a yield advantage of about 0 to $500 \mathrm{lb} / \mathrm{A}$, as well as a reduction in tomato spotted wilt virus, with twin row peanuts compared to single-row planting (Georgia 06G has not shown as high of a yield advantage to twin rows). Other advantages with twin rows include the lapping of row middles as much as two weeks earlier, which aids in weed control and gives higher grades, because peanut tends to put on more of a taproot crop and less of a limb crop. These factors result in more value for the grower. But can strip-till peanut be planted in twin rows? Yes, but it is a little more difficult because both rows need to be planted over a single subsoil slot. Most strip-till rigs will tear up a strip through the cover crop about 8 to 10 inches wide. This is enough to allow twin rows to be planted on either side of the slot. However, it is often necessary to apply more down pressure on the planting coulters to make sure that seed depth can be sustained. Additionally, the sets of twin rows being plowed with the same plow should be 36 inches to the outside of the twin rows. This may mean moving in the subsoil feet on those rows by 7 to 9 inches to ensure that the rows are planted on either side of the subsoil slot. However, in heavy residue, there is often straw that may interfere with planter operation, and seed are often left on the surface when planting through a thick mat of straw. Most planters can be equipped with row cleaners which will physically remove straw in front of the double disk of the planters. Even with these, plant populations are often slightly less in twin-row strip-tilled peanuts compared to twin-row conventionaltilled planted peanuts, although yields are often similar. Six seed per foot of row are recommended in single rows and three seed in each of the double rows for the same seeding rate on an acre basis. A stand of four plants per foot of row is critical for areas where tomato spotted wilt is a problem. Running the strip-till rig twice will help eliminate some of the stand problems with strip-till peanuts.

\section{In-Season Management and Pest Control}

Cover crops, insects, and weeds are the first problems encountered with strip-till peanuts at or soon after planting. A good kill of the cover crop and weeds before planting is essential to successful peanut production. If peanuts are given an early competitive advantage, they will spread and lap sooner, making weed control less expensive and resulting in higher yields. Generally, weed control options in strip-till peanuts are the same as those in conventional till systems. See EDIS document SS-AGR-03, Weed Management in Peanuts (https://edis.ifas.ufl.edu/wg008), for a complete list of materials and weeds controlled. Cover crops are killed by herbicides prior to strip-till planting, and herbicides replace plowing in conventional tillage at a fraction of the cost. Some weeds such as Florida pusley and Palmer amaranth can be controlled with preemergence residual herbicides. However, if weeds escape at plant applications of herbicides, there are good options for control of small weeds during the season. Cultivation of peanut should be avoided during the growing season if weeds can be controlled by chemicals. If peanuts are planted into a high-residue cover crop, residue will decay during the growing season, leaving a mellow surface for peg penetration and good water infiltration. If there are weed escapes that cannot be chemically controlled, high-residue cultivators do a very good job of cutting weed roots while maintaining surface residue. Plowing depth of high-residue cultivators is slightly deeper than in conventional cultivation. Therefore, take care to avoid pruning peanut roots. With the wide array of herbicides on the market, farmers rarely plow peanuts after planting, and conventional tilled peanuts normally have the same weed control program as strip-tilled peanuts after planting.

Insect control in strip-tillage differs little from conventional tillage, except in a few instances. If peanuts are planted within a couple of weeks after the cover crop is killed, cutworms can be more of a problem. However, if the cover crop is killed 3-5 weeks ahead of planting, cutworms pose no greater problem than they do with conventional tillage. Lesser cornstalk borers prefer loose, dry, sandy soils and are less of a problem in strip-till crops than in conventional tillage. Extended hot, dry conditions can lead to outbreaks of lesser corn stalk borer in all types of plantings, but damage will be less for strip-tilled peanuts than peanuts planted into tilled fields. Thrips numbers have been shown to be lower in strip-tillage fields (Knight et al. 2017), and therefore show a reduction in tomato spotted wilt. Strip-tillage is a factor in the TSWV Index developed by the University of Georgia and reviewed annually by scientists from the tri-state area. Reduced tillage is thought to increase the number and diversity of beneficial insects. However, insect problems are not the major consideration for growers in deciding whether to use strip-tillage on peanuts.

Disease and nematode control are usually no different for strip-tilled or conventionally tilled peanuts. As previously mentioned, strip-till peanuts consistently have less TSWV than conventionally tilled peanuts, and recent research in both Georgia and Florida shows that severity of leaf spot is 
also reduced with strip-tillage (Knight et al. 2017). Rotation has much more influence on the number and frequency of fungicide applications than does tillage. Several new peanut varieties with more leaf spot resistance may allow growers to reduce the number of fungicide applications while making comparable or better yields if proper rotations are used.

\section{Harvesting}

No difference in harvesting is noted between strip-tilled and conventionally tilled peanuts. Frequently asked questions by new strip-till peanut farmers are: will the residue from the previous crop interfere with digging; and will there be more foreign material in the harvested peanuts? The answer to both is no. When peanuts are strip-tilled into cotton residue, stalks tend to decay slowly due to their high fiber content. However, with a cover crop on top of cotton stalks, no impediments to digging or harvesting have been noted due to rapid decay. Peanuts have been strip-till planted into bahiagrass that was killed in the fall, as well as in corn, sorghum, cotton, and soybean residue, without any problem during digging and harvest. Generally, if the striptill rig will plant into the residue without any problems, the peanut plow will not have a problem digging. When digging peanuts planted directly into bahiagrass, digging may be slower, so the plow will need to be set slightly deeper. Dry weather can cause a problem in digging both strip-till and conventionally planted peanuts. Actively growing weeds in the crop at digging and weather conditions cause more problems for both strip-till and conventionally planted peanuts than at planting because these factors knock nuts off of vines.

\section{Summary}

The decision to strip-till plant peanuts can bring many benefits to a farming operation. These include advantages to the soil; reduction in environmental impact; savings in fuel, labor, and equipment repairs; and ultimately more profit. Regardless of the planting method, it is important to plan and evaluate each step and to perform the operation in a precise and timely manner. It may become more important to consider reduced tillage as part of a farming operation in order to meet conservation compliance standards and to qualify for farm payments.

\section{References}

Balkcom, K. S., F. J. Arriaga, K. B. Balkcom, and D. L. Boykin. 2010. "Single- and Twin-Row Peanut Production within Narrow and Wide Strip Tillage Systems." Agron. J. 102. doi: 10.2134/agronj2009.0034

Gascho, G. 1996. "Aglime: A Low Cost Alternative Source of Calcium for Peanuts." Better Crops 80(1).

Knight, I., G. Rains, A. Culbreath, and M. Toews. 2017. "Thrips Counts and Disease Incidence in Response to Reflective Particle Films and Conservation Tillage in Cotton and Peanut Cropping Systems." Entomol. Exp. Appl.162(1): 19-29. doi: 1111/eea.12523 
Table 1. Tillage influence on peanut yield in fall-killed bahiagrass or after cotton, either turned or strip-tilled (FL).

\begin{tabular}{|l|c|c|c|}
\hline & Yield (lb/A) & TSWV Incidence \\
\hline Turned bahiagrass & 5,950 & 22.2 & White Mold \\
\hline Strip-till bahiagrass & 5,830 & 10.0 & 3.6 \\
\hline Turned cotton & 5,320 & 20.4 & 3.2 \\
\hline Strip-till cotton & 5,160 & 10.2 & 6.6 \\
\hline LSD & 271 & 7.7 \\
\hline
\end{tabular}

